\title{
THE KEY TO SUCCESS: BUILDING SPEAKING COMPETENCE THROUGH PROBLEM BASED LEARNING (PBL) FOR REAL COMMUNICATION
}

\author{
Stella Prancisca, M.Pd ${ }^{1}$ \\ Tanjungpura University, Pontianak, West-Kalimantan, Indonesia \\ stellaguru344@yahoo.com
}

\begin{abstract}
Speaking is a crucial part in English as a foreign language teaching and learning because the success of English mastery can be measured if the students can speak in the target language (Nunan: 2003). Unfortunately, although English has been taught for many years in Indonesia, only a few of Indonesian students have a good mastery in speaking. There are many challenges that the students face. These include low mastery of English (pronunciation, vocabulary, and grammar), high use of mother tongue in English class, limited opportunities to explore the students' potentials in speaking, speaking activities were dominated by talkative students, and students who are not enthusiastic or interested in joining the speaking activities.

To improve this condition, Problem Based Learning (PBL) can be a good alternative in teaching speaking. PBL is a motivating way to learn because learners are involved in active learning and working with real problems and what they have to learn in their class seen as important and relevant to their own lives. Speaking is no longer a repetition of drills or memorization of dialogue but it uses as a real communication. This study is aimed at finding out whether the implementation of PBL improves the students speaking competence. It will also describe the teaching and learning conditions in which PBL is implemented in the classroom.
\end{abstract}

Keywords: teaching speaking, PBL, real communication.

\section{Introduction}

Language has an important role in developing the learner's intellectual, social, and emotional, value and it supports the successes in learning all subject matter especially in the university level. The idea is supported by Lewis and Hill who state that language is not used for its own sake; it is used for purpose-to convey information, emotion and attitude; to help the memory in

${ }^{1}$ Stella Prancisca adalah dosen UPT Bahasa Untan 
note taking, to entertain and instruct in play, to explore feelings and understanding in feelings. The ability to speak in a foreign language is at the very heart of what it means to be able to use a foreign language. One's personality, self image, knowledge of the world and ability to reason and express one's thoughts are all reflected in his spoken performance in a foreign language.

Especially in university level, the ability to master foreign language especially English is very crucial. The purpose of teaching English is to support the students to improve their communicative competence that would help them to communicate in English in higher education setting as well as in their future jobs or employments. But unfortunately, there were many obstacles in improving speaking competence for the students. It was noticed that they still had many difficulties in improving their speaking competence. In other words, the students had low competence in speaking English. The low competence in speaking was indicated by the following situation: first, it was related to low mastery of English (vocabulary, grammar, pronunciation) which made the students unable to say words or express their feeling or opinion using appropriate vocabularies and grammar in correct pronunciation. They tended to be quiet during the English lesson. Second, the students rarely practiced to use English to communicate. They were many activities that were concentrated on writing form. Speaking activities were very limited. There were very limited opportunities to explore the students' potentials in speaking. Third, the students got used to speak in their mother tongue. This condition also made the situation worse. Fourth, the speaking activities were dominated by talkative students. There were only little opportunities for passive students to practice speaking English or share their opinion in speaking activities. Fifth, the students were not enthusiastic and interested in joining the speaking activities. Only few students had great willingness to speak up voluntarily. Most of them were passive, most of the speaking activities were dominated by the lecturer.

Realizing the condition, I propose an appropriate method to build the students' speaking competence through Problem-Based Learning (PBL). PBL facilitates the students to use the language as a means of effective communication.

\section{Teaching Speaking \\ The Concept of Teaching Speaking}

Speaking is a crucial part of second language learning and teaching. Despite its importance, for many years, teaching speaking has been undervalued and English language teachers have continued to teach speaking just as a repetition of drills or memorization of dialogues. However, today's 
world requires that the goal of teaching speaking should improves students communicative competence, because only in that way, students can express themselves and learn how to follow the social and cultural rules appropriate in each communicative circumstance.Nunan (in Kayi, 2006) states that teaching speaking is to teach ESL learners to: (1)Produce the English speech sounds and sound patterns. (2) Use word and sentences stress, intonation patterns and the rhythm of the second language. (3) Select appropriate words and sentences according to the proper social setting, audience, situation and subject matter. (4) Organize their thought in a meaningful and logical sequence. (5) Use language as a means of expressing values and judgments. (6) Use the language quickly and confidently with few unnatural pauses, which is called as fluency.

Besides, Lawtie (2004) proposes two reasons for teaching speaking in the classroom. Firstly, motivation. Many students equate being able to speak a language as knowing the language and therefore, view learning the language as learning how to speak the language or as Nunan (in Lawtie, 2004) wrote, "Success is measured in terms of the ability to carry out a conversation in the target language." Therefore, if students do not learn how to speak or do not get any opportunity to speak in the language classroom they may soon get demotivated and lose interest in learning. On the other hand, if the right activities are taught in the right way, speaking in class can be a lot of fun, raising general learner motivation and making the English language classroom a fun and dynamic place to be. Secondly, speaking is fundamental to human communication. In our daily lives most of us speak more than we write, yet many English teachers still spend the majority of class time on reading and writing practice almost ignoring speaking and listening skills. If the goal is truly to enable the students to communicate in English, then speaking skills should be taught and practiced in the language classroom.

In teaching speaking, questions such as the following should be considered: Who are the students? Why are they there? What do they expect to learn? What am I expected to teach (Lazaraton, in Murcia 2001:104). One basic consideration is the level of the students and their perceived needs. With low level adults, it will be especially important with this student group to build on their experiences, to share expertise, and to use realia in order to keep learning as concrete as possible. If learners have not got used to work in pairs and groups, teacher will need to introduce ways of working with care; (1) introduce pair and group work gradually. First get the class used to do very simple activities, like practicing the language they are confident with. The activities should not be too long-for example, teacher could introduce a short one at the end of a lesson; (2) tell the learners who to work with rather than to give a vague instruction like find a partner or get into groups of four. If the 
class is working in pairs the teacher has an odd number of learners; (3) it is important to give clear signals to show when each stage of the activity begins and ends. For example, when the teacher wants learners to begin an activity the teacher should say 'Start now' or 'Go', and when the teacher wants them to stop, he should clap his hands, ring bell, or perhaps most effective-silently raise his hand. The teacher can teach them to raise their hands too as they stop talking.

\section{Problems in Speaking Class}

Teaching a heterogeneous class of learners in an English speaking environment, presents certain additional challenges for the teacher. According to Nunan (in Murcia, 2001:110) he found the biggest challenges in EFL classroom as follows: (1) Lack of motivation, many students equate being able to speak a language as knowing the language and therefore view learning the language as learning how to speak the language, or as Nunan (1991) wrote, "success is measured in terms of the ability to carry out a conversation in the (target) language." Therefore, if students do not learn how to speak or do not get any opportunity to speak in the language classroom they may soon get demotivated and lose interest in learning. On the other hand, if the right activities are taught in the right way, speaking in class can be a lot of fun, raising general learner motivation and making the English language classroom a fun and dynamic place to be. (2) Speaking is fundamental to human communication. Just think of all the different conversations you have in one day and compare that with how much written communication you do in one day. Which do you do more of? In our daily lives most of us speak more than we write, yet many English teachers still spend the majority of class time on reading and writing practice almost ignoring speaking and listening skills. Do you think this is a good balance? If the goal of your language course is truly to enable your students to communicate in English, then speaking skills should be taught and practiced in the language classroom. (3) Students won't talk or say anything. One way to tackle this problem is to find the root of the problem and start from there. If the problem is cultural, that is in your culture it is unusual for students to talk out loud in class, or if students feel really shy about talking in front of other students then one way to go about breaking this cultural barrier is to create and establish your own classroom culture where speaking out loud in English is the norm. One way to do this is to distinguish your classroom from other classrooms in your school by arranging the classroom desks differently, in groups instead of lines etc. or by decorating the walls in English language and culture posters. From day one teach your students classroom language and keep on teaching it and encourage your students to ask for things and to ask 
questions in English. Giving positive feedback also helps to encourage and relax shy students to speak more. Another way to get students motivated to speak more is to allocate a percentage of their final grade to speaking skills and let the students know they are being assessed continually on their speaking practice in class throughout the term. A completely different reason for student silence may simply be that the class activities are boring or are pitched at the wrong level. Very often our interesting communicative speaking activities are not quite as interesting or as communicative as we think they are and all the students are really required to do is answer 'yes' or 'no' which they do quickly and then just sit in silence or worse talking noisily in their L1. So maybe you need to take a closer look at the type of speaking activities you are using and see if they really capture student interest and create a real need for communication. Another way to encourage your students to speak in English is simply to speak in English yourself as much as possible in class. If you are shy about speaking in English, how can you expect your students to overcome their fears about speaking English? Don't worry if you are not completely fluent or don't have that elusive perfect native accent, as Swain (1985) wrote "We learn to speak by speaking" and that goes for teachers as well as students. The more you practice the more you will improve your own oral skills as well as help your students improve theirs. (4) When students work in pairs or groups they just end up chatting in their own language. Is the activity or task pitched at the right level for the students?

Make sure you give the students all the tools and language they need to be able to complete the task. If the language is pitched too high they may revert to their L1, likewise if the task is too easy they may get bored and revert to their L1. Also, be aware of the fact that some students especially beginners, will often use their L1 as an emotional support at first, translating everything word for word to check they have understood the task before attempting to speak. In the case of these students simply be patient as most likely once their confidence grows in using English their dependence on using their L1 will begin to disappear. Are all the students actively involved and is the activity interesting? If students do not have something to say or do, or don't feel the need to speak, you can be sure it won't belong before they are chatting away in their L1. Was the timing of the activity good? The timing of a speaking activity in a class can be crucial sometimes. How many teachers have discovered that their speaking activity ended up as a continuation of the students break-time gossip conducted in the L1? After break-time, why not try giving students an activity to calm them down and make them focus before attempting speaking activities that involve groups or pair work. Another way to discourage students speaking in their L1 is to walk around the classroom monitoring their 
participation and giving support and help to students as they need it. If certain students persist in speaking in the L1 then perhaps you should ask them to stay behind after class and speak to them individually and explain to them the importance of speaking English and ask them why they don't feel comfortable speaking in English in the class. Maybe they just need some extra reassurance or they don't like working with certain students or there is some other problem that you can help them to resolve. (5) When all the students speak together it gets too noisy and out of hand and the teacher lose control of the classroom. First of all separate the two points a noisy classroom and an out-of-control classroom. A classroom full of students talking and interacting in English, even if it is noisy, is exactly what you want. Maybe you just feel like you are losing control because the class is suddenly student-centered and not teachercentered. This is an important issue to consider. Learner-centered classrooms where learners do the talking in groups and learners have to take responsibility for using communicative resources to complete a task are shown to be more conducive to language learning than teacher-centered classes (Long \& Richards, 1987). Nevertheless, many classrooms all over the world continue to be teacher-centered, so the question you have to ask yourself is, how learnercentered is my classroom? Losing control of the classroom, on the other hand, is a different issue. Once again walking around and monitoring the students as they are working in groups can help, as you can naturally move over to the part of the classroom where the noise is coming from and calm the rogue students down and focus them back on the task without disrupting the rest of the students who are working well in their groups. If students really get too rowdy then simply change the pace of the class and type of activity to a more controlled task, for example a focus on form or writing task where students have to work in silence individually. Once the students have calmed down you can return to the original or another interactive group activity.

Therefore, Lazaraton in Murcia (2001: 110) suggests solutions to these problems. According to him, when teaching speaking skill, EFL teachers need to be particularly adept at organizing class activity that are authentic, motivating, and varied. The use of authentic, engaging materials should be the basis for in-class activities. If the necessary technology is available, showing movies or recorded television program and playing audiotapes of programs can be enjoyable for students and can provide them with authentic practice in listening to native speaker speech. The teacher can also assign out-of-class learning activities, such as watching and/or listening to an English language film, television show, or radio program. This material then becomes input for subsequent in-class activities such as oral reports or discussions. Student can be encouraged or assigned to go to English speaking businesses or 
embassies/consulates to find native speakers to observe or interact with. They can also be encouraged to start an English club and or to find an English speaking conversation partner. Finally, the teacher can invite native English speakers to the class to give speeches, talks, or presentations. Followed by questions from the students; learners can also be assigned to interview or interact with the guest speakers.

\section{Problem-Based Learning}

Today's world brings with it a rapid explosion of easily accessible knowledge. Today graduates need to be self-directed and possess lifelong learning skills. They need to be critical thinkers, problem solvers and analytical in their approach. The inter-disciplinary nature of work means that they need to be able to integrate knowledge and skills from a number of disciplines as well as have the interpersonal skills to be an effective team member. Problem-Based Learning activities are designed to develop these skills. According to Boud and Felleti (1997:2), the characteristics of PBL are : (1) Using stimulus material to help students discuss an important problem, question or issue. (2) Presenting the problem as a simulation of professional practice or a 'real life' situation. (3) Appropriately guiding the students' critical thinking and providing limited resources to help them learn from defining and attempting to resolve the given problem. (4) Having students work cooperatively as a group, exploring information in an out the class, wit access to a tutor (not necessarily a subject specialist) who knows the problem well and can facilitate the group's learning process. (5) Getting students to identify their own learning needs and appropriate use of available resources. (6) Reapplying this new knowledge to the original problem and evaluating their learning processes.

In addition, Arens (1998: 348-349), PBL has these special features: (1) Driving question or problem, PBL organizes instruction around questions and problems that are both socially important and personally meaningful to students. They address authentic, real-life situations that evade simple answers and for which competing solutions exist.(2) Interdisciplinary focus, in PBL the solution of the problem requires students to delve into many subjects. (3) Authentic investigation, PBL necessitates that students pursue authentic investigations that seek real solutions to real problems. They must analyze define the problem, develop hypo these and make predictions, collect and analyze information conduct experiments (if appropriate), make inferences, and draw conclusions. (4) Production artifacts and exhibit, PBL requires students to conduct products in the form of artifact and exhibits that explain or represent their solutions. The product should be a mock debate, a report, a physical model, a video, or a computer program. (5) Collaboration, PBL is 
characterized by students working with one another most often in pairs or small groups.

\section{Implementing Problem-Based Learning (PBL) Instruction in a Language Classroom}

Within the field of language learning and teaching, PBL engages language students in learning how to learn while they also learn language and content. Mathews-Aydinli (2007) has also concluded the four main steps of PBL process for the students which are: (1) being introduced to the problem; (2) exploring what they do and do not know about the problem; (3) generating possible solutions to the problem and; (4)considering the consequences of each solution and selection the most viable solution.

Furthermore, According to Arends (1998:355-362), in conducting PBL, teacher needs to follow these steps:

\section{Planning Tasks}

In order that the lesson runs smoothly, the teacher needs to plan it first. The planning tasks consist of: (1) Deciding on objectives, PBL is designed to help achieve such goals as enhancing intellectual and investigative skills, understanding adult roles, and helping the students to become autonomous learners. It is important to decide on objectives ahead of time so that they can be communicated clearly to the students. (2) Designing appropriate problem situations. Designing appropriate problem situations or planning ways to facilitate the planning process is a critical planning task for teachers. Duch (2001:48-49) proposes characteristic of good PBL problem: a. An effective problem must first engage students' interest and motivate them to probe for deeper understanding of the concepts being introduced. It should relate the subject matter to the real worlds as much as possible. If the problem is faced in a context in which the students are familiar, they will feel that they have a stake in solving the problem. b. Problems that work well sometimes require students to make decisions or judgments based on facts, information, logic and/or rationalization. In this kind of problem, students will be asked to justify their decisions and reasoning based on the principles being learned. Problems may require students to decide what assumptions are needed (and why), what information is relevant, and/or what steps or procedures are required in order to solve the problem. c. The problem should be complex enough that cooperation from all members of the student group will be necessary in order for them to effectively work toward a solution. The length and complexity of the problem or case must be such that students soon realize that a "divide and conquer". d.The initial questions in the first stage of a problem should be open-ended, 
based on the previously learned knowledge, and/or be controversial so that all students in the groups are initially drawn into a discussion on the topic. The strategy keeps the students functioning as a group, rather than encouraging them to work individually at the outset of the problem. e. The concept objectives of the course should be incorporated into the problems, connecting previous knowledge to new concept, and connecting new knowledge to concepts in other course and/or disciplines.

In brief, a good problem situation must meet at least 5 important criteria. First, it should be interesting, motivated and authentic. Second, the problem should be somewhat ill defined as pose a sense of mystery or puzzlement. Third, the problem should be complex and broad which cooperation from all members are required to solve the problem. Fourth, a good problem should benefit from group effort, not hindered by it. Finally, a good problem should be able to accomplish their instructional goals. Writing Problem-Based Learning problems may be time consuming, challenging, and sometimes frustrating. However, the process, of thinking through the learning priorities of a course and finding, adapting, or writing complex, realistic materials to meet those learning priorities will change how an instructor views his or her course in the future. Any magazine or newspaper article, documentary, news report, book or movie that is seen will become possible material for new problems in Problem-Based Learning. (3) Organizing resources and planning logistics, getting resources organized and planning the logistics of students investigations are major planning tasks for PBL teachers. PBL teachers are responsible for an adequate supply of materials and other resources available for use by investigate teams. When needed materials exist within the school, the primary planning task for teacher is to gather them and make them available to the students.

\section{Interactive Tasks}

There are five phases in interactive tasks. They are:(1) Orienting students to the problem. At the start of a problem-based lesson, teacher should communicate clearly the purposes of the lesson, establish a positive attitude toward the lesson, and describe what students are expected to do. The teacher needs to present the problem situation with care or have clear procedures for involving students in problem identification. The problem situation should be conveyed to students as interestingly and accurately as possible. Usually being able to see, listen, or feel, generates interest and motivates inquiry. Often the use of discrepant events (a situation where the outcome is unexpected and surprising) can prick students' interest. The presentation of the problem must captive students' interest and produce curiosity and excitement because the 
orientation to the problem situations sets the stage for the remaining investigation. (2) Organizing students for study. Problem-based learning requires developing collaboration skills among students and helping them to investigate problems together. It also requires helping them plan their investigative and reporting tasks. In this phase, students form learning-team. After forming the team, teacher and students spend considerable time defining specific subtopics, investigative tasks and time lines. (3) Assisting independent and group investigation. Investigation whether done independently, in pairs, or in small learning teams is the core of problem-based learning. Although every problem situation requires slightly different investigative technique, must involve the process of data gathering and experimentation, hypothesizing and explaining, and providing solutions. (4) Developing and presenting artifact and exhibits. The investigative phase is followed by the creation of artifacts and exhibits. Artifacts are more that written reports. The artifacts can be videotapes that show the problem situation and proposed solutions, models that comprise a physical representation of the problem situation or its solution, poster display, etc. The sophistication of particular artifacts depends on the students ages and abilities. After artifacts are developed, teachers often organize exhibit to display students' work publicly. Exhibit can be a traditional fair or a verbal and/or visual presentation, where ideas are exchanged and feedback is provided. (5) Analyzing and evaluating the problem solving process. The final phase of Problem-Based Learning involves activities aimed to help students analyzed and evaluate their own thinking processes as well as the investigate and intellectual skills they used. During this phase, teacher asks students to reconstruct their thinking during the various phases of the lesson.

\section{Conclusion}

The implementation of Problem-Based Learning (PBL) contributes some significant progresses on the students' speaking competence. First, the students' speaking competence enhances by applying PBL in speaking class. They can perform their speaking competence more confidently, more fluently, and more accurately. The students also can minimize the mistakes in pronunciation, vocabulary, and grammar. They perform more naturally than before the implementation of PBL. Second, the students' psychological problems decrease very effectively. The students who used to feel shy, nervous, inferior, and afraid of making mistakes, have shown some changes. The students begin to have confidence to ask, to share and to respond to their friends or their teacher in their group or individually. The students talk a lot during the teaching-learning process, the class atmosphere changes into active situation. Third, the students' motivation also increase.They are highly 
motivated. They show better participation and cooperation in joining the teaching-learning process. They involved in active learning. Fourth, the application of group work in PBL was considered very effective in encouraging the students to think more and to speak more. In their small learning teams, the students bring and share together collective skill at acquiring, communicating, and integrating information. They support one another to share their opinions about certain matters during the English lesson time. Fifth, the students' ability in solving problems improved. This method challenges the students to develop the ability to think critically, to analyze the problems, to find and to use appropriate learning resources. The students are progressively given more and more responsibility and become increasingly independent for their education. Sixth, the students' attitude shows a good improvement. In their team they are trained to work and cooperate among their team members. They are also trained to appreciate their friends' opinions. They learn how to behave properly in their group. They learn to be social creatures rather than to be individual creature.

\section{BIBLIOGRAPHY}

Boud, David and Felleti Graham I. (1997). The Challenge of Problem-Based Learning. ( $2^{\text {nd }}$ ed). London: Kogan Page Limited.

Brown, H. Douglas. (2004). Language Assessment Principles and Practices. San Francisco: Pearson Education. Inc.

Brown, H. Douglas. (2001). Teaching by Principles. New York: Longman.

Creswell, John W. (2008). Educational Research: Planning, Conducting, and Evaluating quantitative and Qualitative Research. ( $3^{\text {rd }}$ ed). New Jersey: Pearson Education, Inc.

Duch,Barbara J.,Groh Susan E., and Allen Deborah E. (2001). The Power of Problem-Based Learning. Sterling, Virginia: Stylus Publishing.

Gallagher, S. A. (1997). Problem-based learning: Where did it come from, what does it do, and where is it going? Journal for the Education of the Gifted, 20 (4), 332-362.

Harmer, Jeremi. (2006). The Practice of English Language Teaching. ( $4^{\text {th }}$ ed). London: Longman.

Kayi, Hariye. (2006). Teaching Speaking: Activities to promote Speaking in Second Language. Available at: http://unr.edu/homepage/hayriyek

Lawtie, Fiona. (2004). Teaching Speaking Skills 2-Overcoming Classroom Problems. Caracas: British Council.

Mathews-Aydinli, J. (2007). Problem-Based Learning and Adult English LanguageLearners. in Center for Adult English Language Acquisition (CAELA).Washington, DC : Center for Applied Linguistics. 
Murcia. M. (2001). Teaching English as a Second or Foreign Language. ( ${ }^{\text {rd }}$ ed). New York: Heinle\&Heinle.

Nunan, David. (2003). Practical English Language Teaching. New York: McGraw-Hill.

Richards, Jack C and Renandya, Willy A. (2002). Methodology in Language Teaching. New York: Cambridge University Press.

Richard, Jack.,Hull,Jonathan.,and Proctor Susan. (1997). New Interchange: English for International Communication Student's Book 2. New York: Cambridge University Press.

Richard, Jack.,Hull,Jonathan.,and Proctor Susan. (1997). New Interchange: English for International Communication Student's Book 3. New York: Cambridge University Press.

Riddell, David. (2003). Teach Yourself: Teaching English as a Foreign/Second Language. Chicago: McGraw-Hill Companies.

Stringer, E.T. (1999). Action research. Thousand Oaks: Sage.

Thornburry, Scott. (2005). How to Teach Speaking. Edinburgh: Longman

Wee Keng Neo. L. (2004). Jump Start Authentic Problem-Based Learning. Jurong. Singapore: Prentice Hall.

Weir, Cyril J. (1998). Communicative Language Testing. New York: Prentice Hall.

Wilkerson, L. (1996). Tutors and small groups in problem-based learning: Lessons from the literature. In L. Wilkerson \& W. H. Gijselaers (Eds.), Bringing problem based learning to higher education: Theory and practice.San Francisco:Jossey-Bass.

Wilkerson, L and Gijselaersn W.H. (1996). Concluding Comments. In L. Wilkerson \& W. H. Gijselaers (Eds.), Bringing problem based learning to higher education: Theory and practice. San Francisco:Jossey-Bass. 